本ず被覆内の分光スペクトル特性と 紫外線照射および除去が茶新芽の品質に及ぼす影響

\author{
京都府農林水産技術センター農林センター茶業研究所* \\ 木村泰子・神田真帆 \\ (平成25年11月13日受理)
}

\title{
Characteristics of the Light Spectrum Environment of Honzu (orthodox shading) Covering Culture and Influence of UV Irradiation or Shielding on the Quality of Tea New Shoots
}

\author{
Yasuko Kimura and Maho Kanda \\ Tea Industry Research Division, Kyoto Prefectural Agriculture, Forestry and \\ Fisheries Technology Center, Agriculture and Forestry Technology Department
}

Summary

The light spectrum environment of covering cluture was investigated.

The spectrum of light transmitted by black synthetic fiber was found to be similar to light from the sun. However, it was observed that UV rays hardly penetrated honzu (orthodox shading), which is thatched with low UV-permeable materials;yoshizu (screens made of reeds); and rice straw.

The influence of UV irradiation and shielding on the quality of new tea shoots was then investigated.

It was found that UV shielding caused new tea leaves to be thinner, while the content of free amino acids, methyl methionine sulfonium chloride(MMSC), and caffeine all increased.

Therefore, the quality of "covering culture" tea depends on the amount of UV irradiation, such that low UV-permeable covering like traditional honzu it contributes to higher quality tea.

Key Words : covering culture tea, ultraviolet (UV) light, covering materials, quality, honzu (orthodox shading), black synthetic fiber shading

キーワード : 被覆茶, 紫外線, 遮光資材, 品質, 本ず被覆, 黒色化学繊維被覆

\footnotetext{
₹611-0022 京都府宇治市白川中ノ薗 1 番地
} 


\section{1 緒 言}

てん茶, 玉露等の被覆茶は, 京都府の茶生 産を代表する茶種である。平成23年度 $(2011$ 年）京都府茶業統計による府内のてん茶, 玉露, かぶせ茶の生産量は, 荒茶生産総量 2,529トンに対して，それぞれ753トン，146 トン, 312 トンを占め ${ }^{\dagger 1}$, てん茶, 玉露は全 国 1 位を誇る ${ }^{\dagger 2)}$ 。中でもてん茶は, 近年の 需要の高まりにより, 全国的にみても平成 10 年（1998年）に988トンであった生産量が, 平成 20 年（2008年）には約 1.8 倍の 1,780 トン に急増している ${ }^{\dagger 2}$ 。そのため産地間競争が 激しくなっており, 一層の品質向上を図るこ とが京都府茶生産の契緊の課題となってい る。

被覆茶の品質については「覆い香や覆い味 (以下覆い香味)」不足が指摘される茶も認め られる。気象条件等により期待された被覆効 果が十分に得られない場合もあるが, 覆い香 味不足を解消してより一層の高位平準化を図 るためには, 被覆技術のさらなる改善が必要 である。玉露, てん茶に代表される被覆茶は その遮光資材により品質が大きく異なる。現 在遮光資材の主流である黒色化学繊維（以下 黒色化繊) については，30余年に及ぶ改良が 重ねられてきた。しかし, 黒色化繊被覆によ り得られる茶の品質は, 京都府内で伝統的に 行われている本ず（ほんず）被覆のものに及 ばないと言われ, 本ず被覆茶は市場でも今な お高い評価を受けている。本ず被覆とは，天 然資材のよしずと稲わらを用いた遮光方法で あり,その起源は 16 世紀とされる手法である。 しかし, 年々材料の入手が困難となっており, その設置作業に多くの人手と熟練を要するこ とから, 近年では京都府内でも平成10年 (1998 年)には85haであった面積が，平成23年 (2011 年）には31haへと激減している ${ }^{\dagger 1}$ 。本ず被 覆に匹敵する高品質な茶を持続的に生産する ためには，本ず被覆で生産された茶の品質に 関わる特性や本ず被覆茶園内の環境特性を明 らかにすることが必要である。

被覆技術と品質との関連については, 遮光 率, 遮光資材の種類, 被覆期間について概ね 明らかにされている が が，本ず被覆茶の品 質が黒色化繊被覆のものに優る原因は解明で きていない。筆者らは, まず本ず被覆と黒色 化繊被覆で得られた茶葉を比較し, 旨味成分 である遊離アミノ酸や覆い香の主体である硫 化メチルの前駆体のメチルメチオニンスルフ オニウムクロライド (以下MMSC) 含有量が 高く, 苦渋味を呈するカテキン類含有量が低 いことを報告した ${ }^{1)}$ 。さらに，遮光資材の分 光透過率を比較し，黒色化繊はいずれの波長 域でも同等の透過率を示す資材であるのに対 して，よしずやわらは紫外域光を含む $500 \mathrm{~nm}$ 以下の波長域を透過しにくい資材であること を報告した ${ }^{2)}$ 。中山ら ${ }^{3)} も 500 \mathrm{~nm}$ 以下の波長 域光を除去した条件下では茶新芽のアミノ酸 含有率の低下が抑制されると報告しており, 被覆茶の品質関連成分含有量と500nm以下の 波長域光との関連性を示唆している。500nm 以下の波長域光のうち紫外線には, ポリフ エノール等の品質関連成分との関係について いくつかの研究事例があり, リンゴやブドウ では，成熟期の果実に対する紫外線照射によ る果実のアントシアン含有量の増加が報告

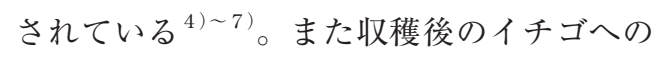
紫外線照射が着色を促進した事例がある ${ }^{8)} 。$ 紫外線を除去した場合についても研究例があ り, 近紫外線除去ではナス果実の黑紫色の発 現が抑制され ${ }^{9)}$, プリムラ・マラコイデスの 緋紅色系品種では花色が薄色になるという報 告がある ${ }^{10)}$ 。被覆茶における紫外線と品質関

\footnotetext{
†1 平成23年度京都府茶業統計 http://www.pref.kyoto.jp/nosan/11700012.html

$\uparrow 2$ 平成 23 年度茶関係資料 : 茶業中央会, p18 (2011)

†3 京都府立茶業研究所：中核研究報告書「化学繊維による覆下茶の品質向上栽培技術」(1982)
} 
連成分との関係では，茶樹が受ける紫外線の 少ない状態が苦渋味を呈するカテキン類等ポ リフェノールの減少につながると考えられ る。また, 旨味を呈する遊離アミノ酸のうち テアニンは, 露光下でカテキン類へ速やかに

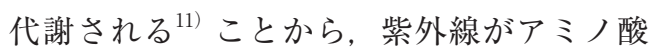
代謝にも関与している可能性が考えられる が, 詳細には検討されていない。

近年，携帯型分光放射計が開発され，350 〜 800nmの波長域の分光放射照度を現場で簡 便に測定できるようになった。本報告では, まず携帯型分光放射計を用いて本ず被覆と黒 色化繊被覆による被覆内の分光スペクトルを 比較した。その結果, 本ず被覆内は黒色化緎 被覆内と比較して紫外域光がほとんど透過し ていないことが明らかになった。次に, 被覆 下での紫外域光の照射又は除去が新芽の遊離 アミノ酸やMMSC, カテキン類, カフェイ ンの含有量及び葉厚に及ぼす影響を調査し, 本ず被覆下での新芽品質が黒色化繊より優れ る要因を検討した。

\section{2 材料及び方法}

\section{1 モデル被覆施設を用いた被覆内光環 境の比較試験}

モデル被覆施設として移動式被覆棚（長さ $4 \mathrm{~m} \times$ 幅 $1.5 \mathrm{~m} \times$ 高さ $1.6 \mathrm{~m})$ を, 京都府農林水 産技術センター農林センター茶業研究所 (以 下茶業研究所）内に写真 1 のように設置し,

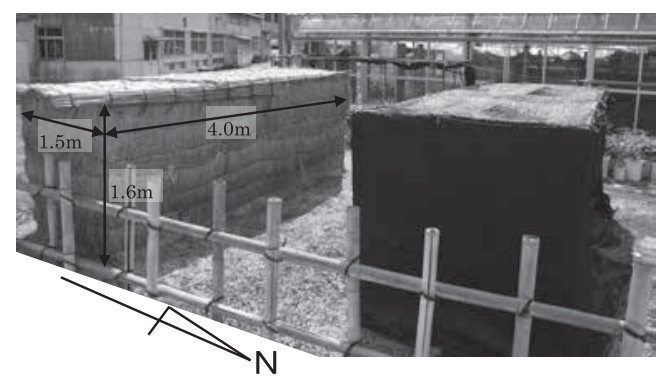

写真 1 モデル被覆施設の設置状況 左：本ず区, 右：黑色化繊区
黒色化繊被覆施設区（以下黒色化繊区)，本 ず被覆施設区（以下本ず区）を設定した。黒 色化繊区は, 被覆棚天井面を, 前期被覆 (2009 年 4 月 1 日〜 4 月 24 日）としてダイオネット R610番（ダイオ化成株式会社製，遮光率約 45\%) 二枚重ね, 後期被覆（2009年 4 月25日 〜 5 月31日）として前期遮光資材上にダイオ ネット $\mathrm{R} 5050$ 番（ダイオ化成株式会社製，遮 光率約 95\%）を重ねて被覆した。被覆棚側面 は前期被覆開始時にダイオネット R5050番 （幅 $2 \mathrm{~m} ）$ で 4 面とも被覆した。

本ず区は，前期被覆としてよしず（よしを ナイロンロープですだれ状に編んだもの，幅 $1.8 \mathrm{~m} \times$ 長さ $1.5 \mathrm{~m} ） 2$ 枚で被覆棚天井面を被 覆し, 後期被覆ではよしずの上に稲わら約 $15 \mathrm{~kg}$ を天井面全体に広げた。また，被覆棚 側面は前期被覆開始時にこも（稲わらをナ イロンロープですだれ状に編んだもの，幅 $1 \mathrm{~m})$ を二枚重ねになるようにナイロンロー プで接続し， 4 面とも被覆した。天井面の稲 わら量は黒色化繊区の照度と同等になるよう に，デジタル照度計（TMS-870H，タスコジ ヤパン社製，光測光用プローブ使用）で確認 しながら微調整した。

紫外線強度は紫外放射計MS-212A（英弘 精機株式会社製，測定波長315４00nm）に より測定した。紫外線強度の測定は2009年に 設置した施設で2009年 4〜 5 月に行った。紫 外線強度の測定は10分間隔で行い, 日の出か ら日の入りまでの測定值の平均を求めて日 平均紫外線強度とした。被覆施設内透過光 の分光スペクトルは分光放射計MS-720（英 弘精機株式会社製, 測定可能波長域300 $1100 \mathrm{~nm} ）$ により測定した。測定は2008年 9 月 1 日に設置した後期被覆施設で 2008 年 9 月 18日に行った。設置方法は2009年のものと同 様とした。それぞれの測定機器は, 茶株面の 高さに相当する地上 $70 \mathrm{~cm} に$ 設置した。また, 対照として露天の太陽光のものも測定した。 


\section{2 苗を用いた紫外線照射試験}

材料として0.5〜 1.0 葉期の ‘さみどり’と‘や ぶきた’の 1 年生セル成型苗（日本製紙株式 会社製)を供試し，2012年に試験を実施した。 トルーライト $\mathrm{R}$ （TRUE-LITE, 輸入元イン ポートライトジャパン株式会社) $15 \mathrm{~W} \times 3$ 本 を光源とした恒温器 (MIR-253, 三洋電機株 式会社製）を 2 台用意し，明期を $25^{\circ} \mathrm{C} / 16$ 時 間, 暗期を $15^{\circ} \mathrm{C} / 8$ 時間周期とした。一方の 恒温器内には, ブラックライト (FL10BLB, 東芝電器株式会社製, ピーク波長 $352 \mathrm{~nm}$ ) $10 \mathrm{~W} \times 3$ 本を併せて設置し, 紫外線を照射し た環境（以下 $+\mathrm{UV}$ 処理）を設定した。紫外 線強度は $2.4 \mathrm{~W} \cdot \mathrm{m}^{-2}$ で曇天時の屋外紫外線強 度に相当した。他方の恒温器内には, $380 \mathrm{~nm}$ 以下を $100 \%$ 遮る紫外線除去フィルム（ハイ エスビニール $\mathrm{R} 0.075 \mathrm{~mm}$ 厚, MKVドリーム 株式会社製）を展張し，紫外線を除去した環 境（以下-UV処理）を設定した。+UV処理 に引き続き $-U V$ 処理することにより紫外線 照射日数の異なる区を設けた。各試験の供試 品種, 照射開始日, +UVと-UVの処理日数 は表 1 に示した。照射試験は 3 回行い, セル 成型苗は 1 区あたり 6 本供試し，それぞれ 4 反復とした。分光スペクトルは, 分光放射計 MS-720により新芽が伸長している位置で測 定した。各試験とも処理終了日に各区の新芽
を 1 心 2 葉で採取し，上位から第 2 葉の葉厚 をマイクロメーターで測定した後, 真空凍結 乾燥後に粉砕して成分分析の試料に供した。

\section{3 ほ場における紫外線除去試験}

試験は，茶業研究所内の ‘さみどり’ 8 年 生弧状仕立てほ場で2012年二番茶期に実施し た。試験区は, 前述の紫外線除去フィルムと ダイオネット R5050番で被覆した区（以下 UVカット区）と紫外線を透過させる塩化ビ ニルフィルムとダイオネット $\mathrm{R} 5050$ 番で被覆 した区（以下塩ビ区）の 2 区とし， 1 区幅 $1.8 \mathrm{~m} \times$ 長さ $1.5 \mathrm{~m}$ の 4 反復とした。二番茶の 1.5 葉期にあたる 2012 年 6 月 28 日に高さ $1.8 \mathrm{~m}$ のアーチパイプを茶株上に設置して，それぞ れのフィルムを展張し, フィルムの上からダ イオネットR5050番で覆った。両区とも茶株 面での遮光率は概ね $298 \%$ であった。分光スペ クトルは分光放射計MS-720により茶株面で 測定した。また, 被覆内の茶株面の気温を温 度計（記憶計 RSK-L200TH II $\alpha$, 株式会社 佐藤計量器製作所製）により 1 時間ごとに測 定した。同年 7 月 19 日に 1 心 3 葉の新芽を 80 本ずつ採取し，紫外線照射試験と同様に上位 から第 2 葉の葉厚を測定後, 成分分析に供し た。

表 1 紫外線照射試験の概要

\begin{tabular}{|c|c|c|c|c|c|c|}
\hline \multirow{2}{*}{$\begin{array}{c}\text { 試験 } \\
\text { No. }\end{array}$} & \multirow{2}{*}{ 品種名 } & \multirow{2}{*}{ 照射開始日 } & \multirow{2}{*}{$\begin{array}{l}\text { 試験 } \\
\text { 区名 }\end{array}$} & \multicolumn{3}{|c|}{ 処理日数 } \\
\hline & & & & $+\mathrm{UV}$ & $-\mathrm{UV}$ & 合計 \\
\hline \multirow{3}{*}{ (1) } & \multirow{3}{*}{ さみどり } & \multirow{3}{*}{9 月 7 日 } & 0 日区 & 0 & 14 & \multirow{3}{*}{14} \\
\hline & & & 6 日区 & 6 & 8 & \\
\hline & & & 14日区 & 14 & 0 & \\
\hline \multirow{3}{*}{ (2) } & \multirow{3}{*}{ さみどり } & \multirow{3}{*}{9 月 21 日 } & 0日区 & 0 & 13 & \multirow{3}{*}{13} \\
\hline & & & 5 日区 & 5 & 8 & \\
\hline & & & 13日区 & 13 & 0 & \\
\hline \multirow{3}{*}{ (3) } & \multirow{3}{*}{ やぶきた } & \multirow{3}{*}{ 10月 22 日 } & $\begin{array}{c}\text { 日区 } \\
\text { 日 }\end{array}$ & 0 & 16 & \multirow{3}{*}{16} \\
\hline & & & 5 日区 & 5 & 11 & \\
\hline & & & 16日区 & 16 & 0 & \\
\hline
\end{tabular}

1区あたりセル苗を 6 本供試，4反復で行った。

+UV : 紫外線強度 $2.4 \mathrm{~W} \cdot \mathrm{m}^{-2}$, PPFD $10.5 \mu \mathrm{mol} \cdot \mathrm{m}^{-2} \cdot \mathrm{s}^{-1}$

- UV: 紫外線強度 $0 \mathrm{~W} \cdot \mathrm{m}^{-2}$, PPFD $10.8 \mu \mathrm{mol} \cdot \mathrm{m}^{-2} \cdot \mathrm{s}^{-1}$ 


\section{4 成分分析}

個別の遊離アミノ酸 ${ }^{12)}$, カテキン類 ${ }^{13)}$ は高 速液体クロマトグラフ（以下HPLC）を用い て, 文献の手法により分析した。MMSCは 既報 ${ }^{14)}$ に準じて分析した。すなわち, 試料 $50 \mathrm{mg} 0.1 \mathrm{~N}$ 塩酸を加え, ホモジナイザーチ ユーブでホモジナイズし，25mLに定容した。 遠心分離により得た上清をポリビニルポリピ ロリドンで除タンニン処理した後, $0.45 \mu \mathrm{m}$ フィルターで滤過したものを試料溶液とし た。後藤ら ${ }^{12)}$ の方法に従い試料溶液をオル トフタルアルデヒドで誘導体化LHPLC分析 に供した。表 2 のHPLC分析装置を用い, 表 3 の移動相により分析した。

\section{3 結果}

\section{1 モデル被覆施設を用いた被覆内光環 境の比較}

モデル被覆施設内と太陽光の分光スペクト ルを図 1 に示した。太陽光の分光スペクトル は450nm付近にピークを持つ山形の波形を示 し, 黒色化繊区の分光スペクトルも分光放射 照度は小さいが，概ね太陽光に近い波形を示 した。一方，本ず区の分光スペクトルは，黒 色化繊区とは大きく波形が異なり，680nm以 下の分光放射照度が小さかった。特に $500 \mathrm{~nm}$

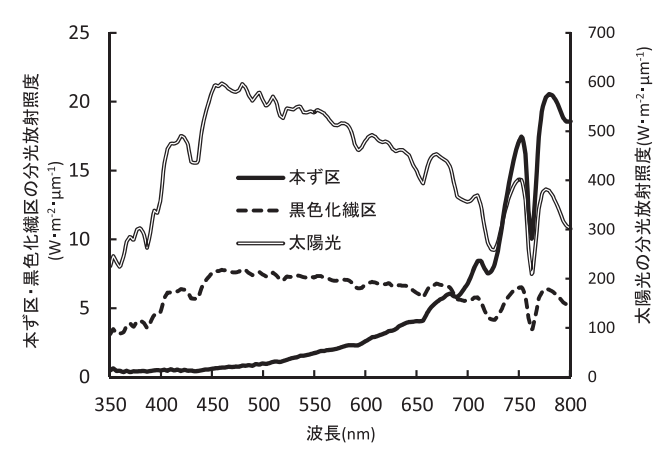

図 1 屋外及びモデル被覆施設内の分光スペクトル 測定日時：2008年 9 月18日午前10時 左軸：本ず区・黒色化緘区，右軸：太陽光

以下の分光放射照度が $1.0 \mathrm{~W} \cdot \mathrm{m}^{-2} \cdot \mu \mathrm{m}^{-1}$ 以下 と非常に小さく, 紫外域光がほとんど透過し ていなかった。また，長波長域ほど分光放射 照度が大きく, 800nm付近では黒色化繊区の 4 倍程度の值を示した。図 1 のデータから算 出した被覆施設内への太陽光の透過率を図 2 に示したところ，黒色化繊区内への透過率が 波長によらず概ね一定であったのに対して, 本ず区では短波長域の透過率が低く，長波長 域の透過率が高かった。すなわち, 黒色化繊 区の光透過性は非選択的であり，本ず区の光 透過性は選択的であるといえた。

\section{表 2 HPLC分析装置の概要}

\begin{tabular}{|c|c|}
\hline 装置 & Prominence LC-20ABシステム（島津製作所） \\
\hline カラム & Develosil ODS-HG-5 ( $\phi 4.6 \times 150 \mathrm{~mm}$, 野村化学 $)$ \\
\hline ガードカラム & Develosil ODS-HG-5（ $\phi 4 \times 10 \mathrm{~mm}$, 野村化学 $)$ \\
\hline 流速 & $1 \mathrm{~mL} / \mathrm{min}$ \\
\hline 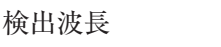 & 蛍光検出 Ex340nm, Em450nm(RF-20Axs) \\
\hline カラムオーブン & $40^{\circ} \mathrm{C} \quad(\mathrm{CTO}-20 \mathrm{AC})$ \\
\hline オートサンプラー & SIL-10AF \\
\hline データ解析ソフト & Lab Solutions version5.51 \\
\hline
\end{tabular}

\section{表 3 移動相の混合比}

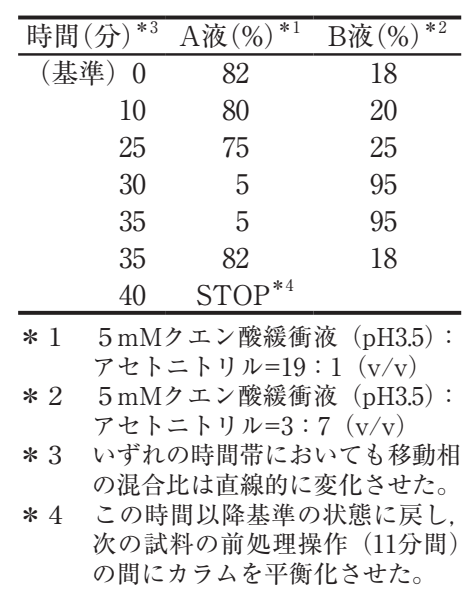




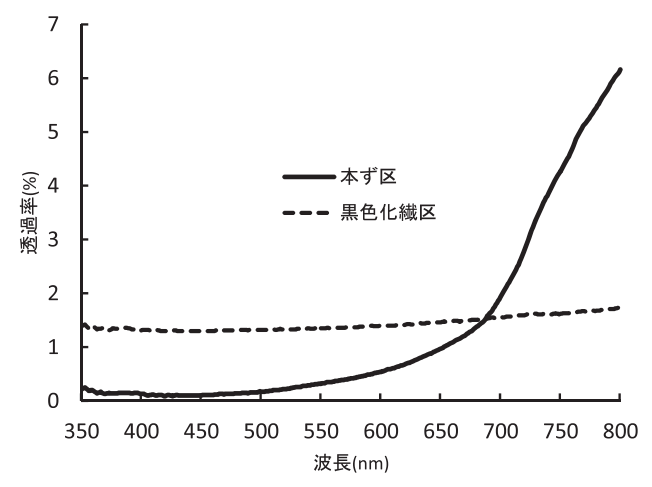

図 2 モデル施設内への太陽光の分光透過率

一番茶被覆期間にあたる 4 月 1 日から 5 月31日までの本ず区と黒色化繊区，太陽光 の日平均紫外線強度 (315〜 400nm) を図 3 に示した。太陽光の日平均紫外線強度は天 候による変動が見られた。測定期間中の最 大值は前期が $19.7 \mathrm{~W} \cdot \mathrm{m}^{-2}$, 後期が $20.0 \mathrm{~W} \cdot \mathrm{m}^{-2}$ であり, 平均值は前期が $13.9 \mathrm{~W} \cdot \mathrm{m}^{-2}$, 後期が $11.8 \mathrm{~W} \cdot \mathrm{m}^{-2}$ であった。黒色化纎区の日平均紫 外線強度は概ね太陽光と同様の動きを示し,
最大值は前期が $3.0 \mathrm{~W} \cdot \mathrm{m}^{-2}$, 後期が $0.2 \mathrm{~W} \cdot \mathrm{m}^{-2}$ であり, 平均值は前期が $2.1 \mathrm{~W} \cdot \mathrm{m}^{-2}$, 後期が $0.1 \mathrm{~W} \cdot \mathrm{m}^{-2}$ であった。一方本ず区の平均紫外 線強度は，期間を通じて黒色化繊区より低く 推移し, 最大值は前期が $1.8 \mathrm{~W} \cdot \mathrm{m}^{-2}$, 後期が $0.1 \mathrm{~W} \cdot \mathrm{m}^{-2}$ であり, 平均值は前期が $1.2 \mathrm{~W} \cdot \mathrm{m}^{-2}$, 後期が $0.03 \mathrm{~W} \cdot \mathrm{m}^{-2}$ であった。天候が安定し 太陽光の紫外線強度変動が小さい日（前期 被覆時 4 月19日，後期被覆時 5 月26日）の 被覆内の日内変化を図 4 に示した。前期被 覆時では，両区とも午前 5 時20分の日の出 時刻から紫外線強度を増し, 最大值は本ず 区が $6.3 \mathrm{~W} \cdot \mathrm{m}^{-2}$ ，黒色化繊区が $6.8 \mathrm{~W} \cdot \mathrm{m}^{-2}$ を示 した。測定日の平均紫外線強度は太陽光が $18.6 \mathrm{~W} \cdot \mathrm{m}^{-2}$ に対して本ず区が $1.6 \mathrm{~W} \cdot \mathrm{m}^{-2}$, 黒色 化繊区が $2.9 \mathrm{~W} \cdot \mathrm{m}^{-2}$ であり，資材間には約 1.8 倍の差がみられた。なお，本ず区では，よし ずの編み目が粗く $0.5 \mathrm{~cm}$ 程度の隙間があるた め, 隙間から太陽光が入り, 高い值を示す時 刻がみられた。後期被覆時では，午前 4 時 47 分の日の出時刻から 2 時間以上遅れて紫外線
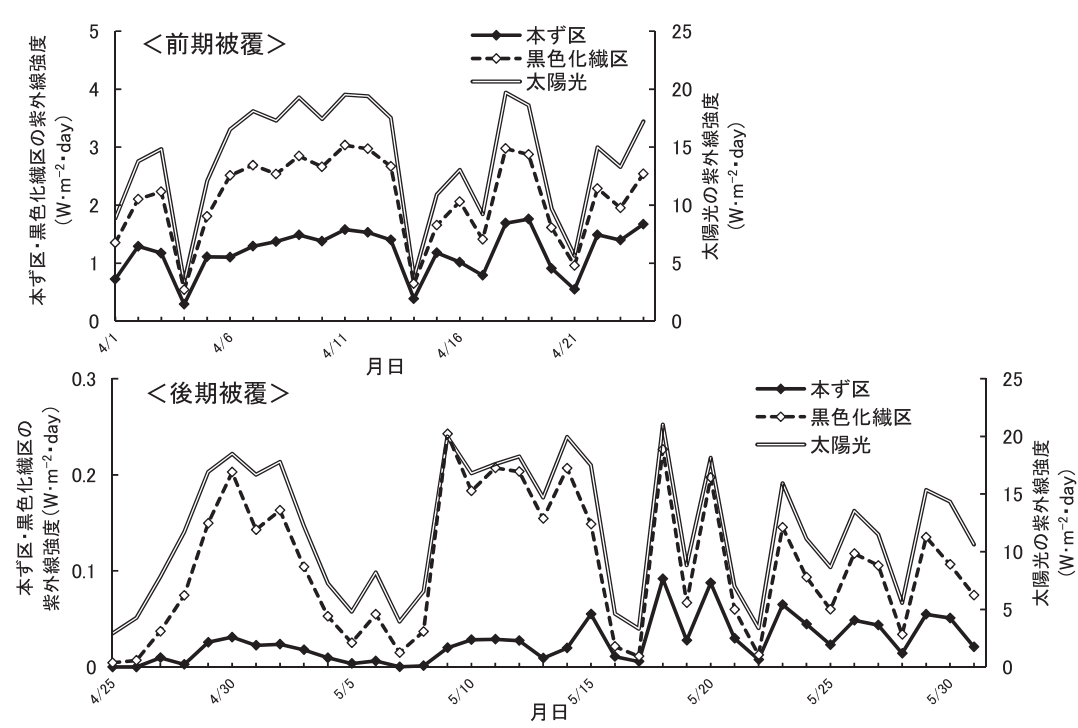

図 3 一番茶被覆期間におけるモデル被覆施設内の日平均紫外線強度の推移 上図：前期被覆 2009 年 4 月 1 日 24日, 下図：後期被覆2009年 4 月 25 日 5 月 31 日 左軸 : 本ず区・黒色化繊区, 右軸 : 太陽光 

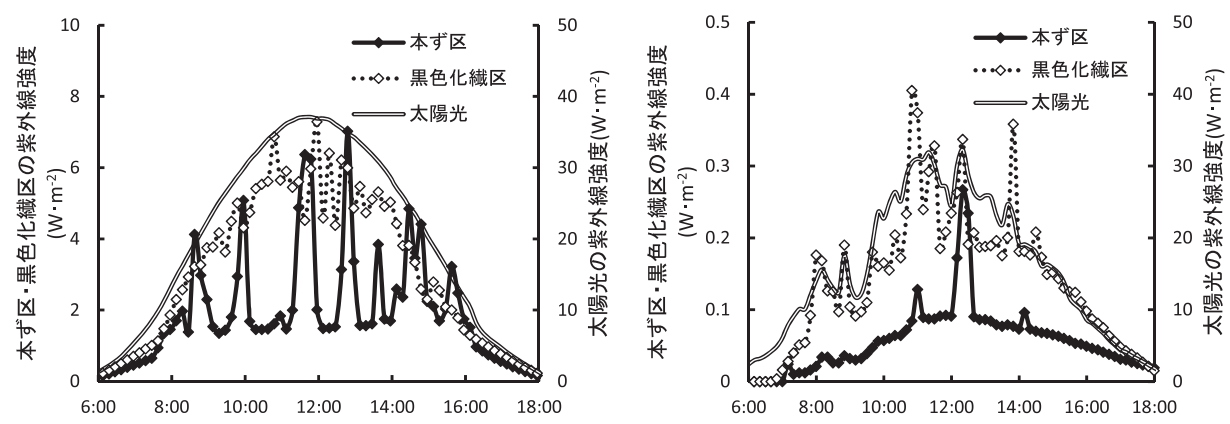

図 4 モデル被覆施設内の紫外線強度の日内变化

左図：前期被覆時2009年 4 月 19 日測定, 右図：後期被覆時2009年 5 月 26 日測定 いずれも左軸：本ず区・黒色化纎区，右軸：太陽光

強度が測定可能な強度となった。最大值は本 ず区が $0.26 \mathrm{~W} \cdot \mathrm{m}^{-2}$ ，黑色化繊区が $0.41 \mathrm{~W} \cdot \mathrm{m}^{-2}$ であった。測定日の平均紫外線強度は, 太陽 光の $13.5 \mathrm{~W} \cdot \mathrm{m}^{-2}$ に対して本ず区が $0.05 \mathrm{~W} \cdot \mathrm{m}^{-2}$, 黒色化繊区が $0.12 \mathrm{~W} \cdot \mathrm{m}^{-2}$ であり，資材間には 約2.4倍の差がみられた。

\section{2 苗を用いた紫外線照射試験}

紫外線照射試験に用いた光源の分光スペク トルを図 5 に示した。両処理の分光スペク トルは紫外域の分光放射照度が大きく異な り, + UV処理は350nm付近に大きなピーク を持ち, $-U V$ 処理は380nm以下の分光放射 照度が $0.1 \mathrm{~W} \cdot \mathrm{m}^{-2} \cdot \mu \mathrm{m}^{-1}$ 以下であった。紫外

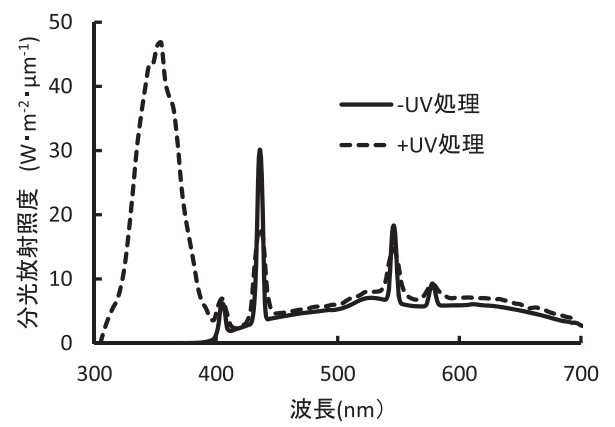

図 5 紫外線照射試験に用いた光源の分光スペクトル 測定日：2012年 9 月 7 日
線強度は $+\mathrm{UV}$ 処理が $2.4 \mathrm{~W} \cdot \mathrm{m}^{-2}, \quad-\mathrm{UV}$ 処理 が $0.0 \mathrm{~W} \cdot \mathrm{m}^{-2}$ で, +UV処理の值は 3.1 で述 べた黒色化繊区における前期被覆期間の平 均值に近かった。光合成有効光量子束密度 (Photosynthetic Photon Flux Density, 以下 PPFD）は, +UV処理が $10.5 \mu \mathrm{mol} \cdot \mathrm{m}^{-2} \cdot \mathrm{s}^{-1}$, - UV処理が $10.8 \mu \mathrm{mol} \cdot \mathrm{m}^{-2} \cdot \mathrm{s}^{-1}$ とほほ同等で あった。これらの值は, $98 \%$ 以上遮光してい る一番茶期本ず被覆下のPPFDに相当した。

各区の葉厚を図 6 に示した。いずれの試験 においても葉厚には紫外線照射による有意な 増加が認められ，紫外線を最も長く照射した 区の葉が最も厚く，除去した 0 日区の葉が最 も薄かった。次に新芽中の成分含有量をみる

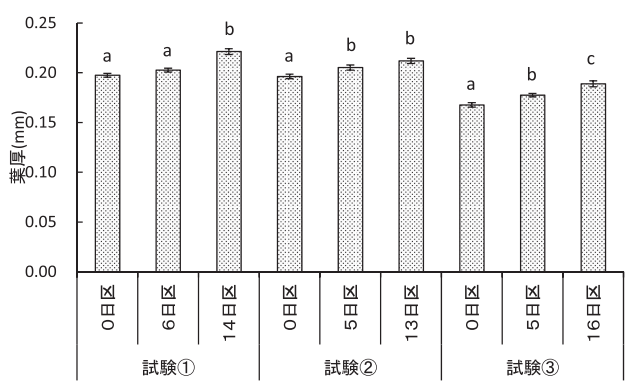

図 6 紫外線照射が新芽葉厚に及ぼす影響 エラーバーは標準誤差を示す。四中の異なる英小文字間には，それ ぞれの試験内で $5 \%$ 水準の有意差あり（Tukey多重検定， $\mathrm{n}=20$ )。 
と, 遊離アミノ酸については, アスパラギン, セリン, アルギニンの含有量に紫外線の照 射による有意な減少が認められ，いずれの試 験においても紫外線を除去した 0 日区と最も 長く照射した区に有意差がみられた（表 4$) 。$ アスパラギン酸とグルタミン酸, グルタミン, テアニンの含有量には, 試験(2)のグルタミン を除いて, 紫外線照射による有意な増減が認 められなかった。MMSCの含有量について は, ‘さみどり’を供した試験(1) と試験(2)で は有意差がなく，‘やぶきた’を供した試験 (3)のみで紫外線照射による有意な減少が認め られた。カテキン類については, エステル型 カテキンのエピガロカテキンガレートとエピ
カテキンガレートの含有量に紫外線照射によ る有意な減少が認められ，いずれの試験にお いても紫外線を除去した 0 日区に比べ最も長 く照射した区の含有量が有意に低かった（表 5 )。遊離型カテキンのエピガロカテキンで は試験(1), 同じくエピカテキンでは試験(2)の みで紫外線照射による有意な減少が認められ た。合計量に占める遊離型カテキンとエステ ル型カテキンの割合には紫外線照射による変 化が認められなかった。カフェインの含有量 については，いずれの試験においても紫外線 を最も長く照射した区が他の区より低く，紫 外線照射による有意な減少が認められた。

表 4 紫外線照射が新芽中の遊離アミノ酸とMMSCの含有量に及ぼす影響

\begin{tabular}{|c|c|c|c|c|c|c|c|c|c|c|}
\hline \multirow{2}{*}{$\begin{array}{l}\text { 試験 } \\
\text { No. }\end{array}$} & \multirow{2}{*}{ 区名 } & \multicolumn{8}{|c|}{ 遊離アミノ酸 $\left(\mathrm{mg} \cdot \mathrm{g}^{-1} \mathrm{DW}\right)$} & \multirow{2}{*}{$\begin{array}{c}\text { MMSC } \\
\left(\mu \mathrm{g} \cdot \mathrm{g}^{-1} \mathrm{DW}\right)\end{array}$} \\
\hline & & アスパラギン酸 & グルタミン酸 & アスパラギン & セリン & グルタミン & アルギニン & テアニン & 計 & \\
\hline \multirow{3}{*}{ (1) } & 0日区 & 2.3 & 3.3 & $8.0 \mathrm{a}$ & $1.2 \mathrm{a}$ & 1.4 & $22.1 \mathrm{a}$ & 4.1 & $42.4 \mathrm{a}$ & 34.0 \\
\hline & 6 日区 & 2.0 & 2.9 & $6.6 \mathrm{a}$ & $1.2 \mathrm{a}$ & 1.3 & $17.3 \mathrm{a}$ & 4.1 & $35.4 \mathrm{a}$ & 31.5 \\
\hline & 14日区 & 2.2 & 3.2 & $3.0 \mathrm{~b}$ & $0.6 \mathrm{~b}$ & 1.2 & $8.5 \mathrm{~b}$ & 4.4 & $23.1 b$ & 24.4 \\
\hline \multirow{3}{*}{ (2) } & 0 日区 & 2.0 & 2.9 & $3.6 \mathrm{a}$ & $0.8 \mathrm{a}$ & $1.2 \mathrm{a}$ & $15.8 \mathrm{a}$ & 3.7 & $30.0 \mathrm{a}$ & 46.4 \\
\hline & 5 日区 & 2.0 & 3.0 & $2.9 \mathrm{a}$ & $0.8 \mathrm{a}$ & $1.0 \mathrm{~b}$ & $14.6 \mathrm{a}$ & 4.6 & $28.9 b$ & 53.4 \\
\hline & 13日区 & 2.1 & 3.1 & $1.4 \mathrm{~b}$ & $0.5 \mathrm{~b}$ & $0.8 \mathrm{~b}$ & $8.1 b$ & 4.7 & $20.7 \mathrm{~b}$ & 28.7 \\
\hline \multirow{3}{*}{ (3) } & 0 日区 & 2.2 & 2.2 & $6.4 \mathrm{a}$ & $1.8 \mathrm{a}$ & 1.1 & $21.0 \mathrm{a}$ & 11.0 & $45.7 \mathrm{a}$ & $25.8 \mathrm{a}$ \\
\hline & 5 日区 & 2.0 & 2.2 & $3.6 \mathrm{~b}$ & $1.3 \mathrm{~b}$ & 1.0 & $16.6 \mathrm{a}$ & 9.5 & $36.2 b$ & 21.3a \\
\hline & 16日区 & 2.5 & 2.5 & $2.9 \mathrm{~b}$ & $0.8 \mathrm{c}$ & 1.0 & $9.5 \mathrm{~b}$ & 11.2 & $30.4 \mathrm{~b}$ & $8.9 \mathrm{~b}$ \\
\hline
\end{tabular}

表中の異なる英小文字間には, それぞれの試験内で $5 \%$ 水準の有意差あり (Tukey多重検定, $\mathrm{n}=4$ )。新芽は 1 芯 2 葉で採取した。

表 5 紫外線照射が新芽中のカテキン類とカフェインの含有量に及ぼす影響

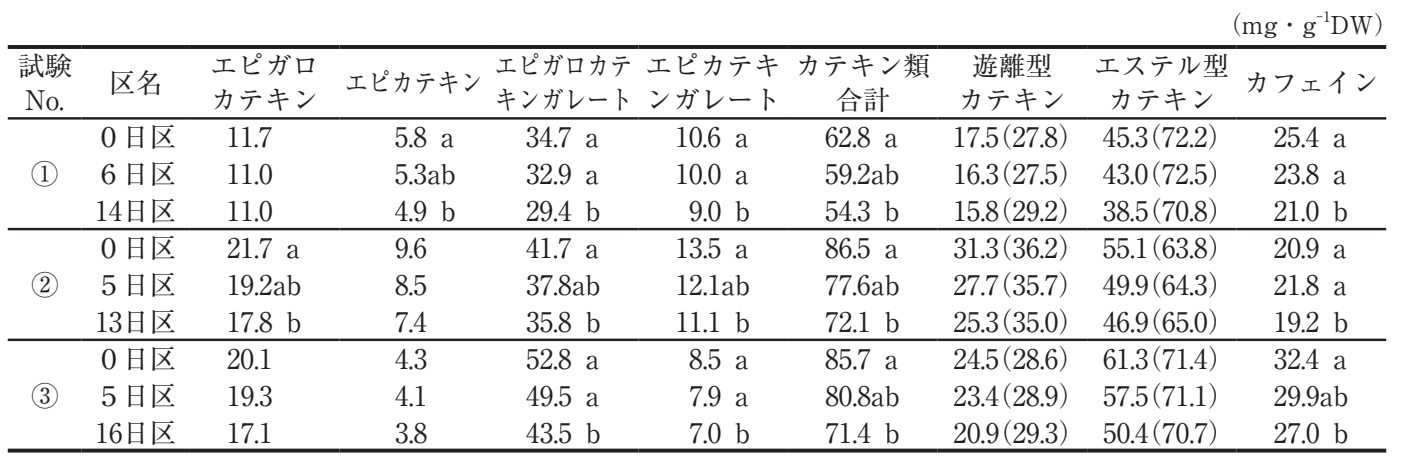

表中の異なる英小文字間は，それぞれの試験内で $5 \%$ 水準の有意差あり (Tukey多重検定, $\mathrm{n}=4$ )。新芽は 1 芯 2 葉で採取した。 遊離型カテキン:エピガロカテキン +エピカテキン, エステル型カテキン:エピガロカテキンガレート+エピカテキンガレート。 表中の（）内の值はカテキン類合計に対する割合。 


\section{3 ほ場（二番茶期）における紫外線除 去試験}

ほ場試験に㧍ける被覆内透過光の分光スペ クトルを図 7 に示した。UVカット区の透過 光は680nm以下の分光放射照度が塩ビ区より 小さく, 380nm以下の紫外域光がほとんど含 まれていなかった。紫外線強度はUVカット 区が $0.0 \mathrm{~W} \cdot \mathrm{m}^{-2}$, 塩ビ区が $0.8 \mathrm{~W} \cdot \mathrm{m}^{-2}$ であった。 $\mathrm{PPFD}, \mathrm{UV}$ カットが $31.5 \mu \mathrm{mol} \cdot \mathrm{m}^{-2} \cdot \mathrm{s}^{-1}$, 塩ビ区が $37.1 \mu \mathrm{mol} \cdot \mathrm{m}^{-2} \cdot \mathrm{s}^{-1}$ であった。また, 測定期間中の平均気温と最高気温, 最低気 温はUVカット区がそれぞれ $26.7^{\circ} \mathrm{C}, 34.9^{\circ} \mathrm{C}$, $19.3^{\circ} \mathrm{C}$, 塩ビ区が $26.6^{\circ} \mathrm{C}, 34.3^{\circ} \mathrm{C}, 19.2^{\circ} \mathrm{C}$ とほ ぼ同等であった。

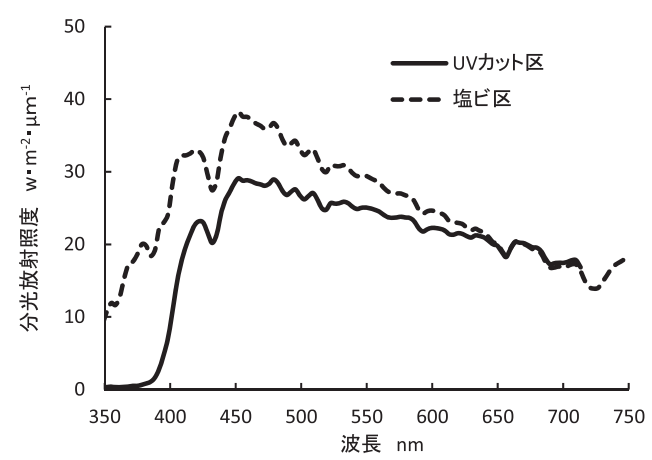

图 7 ほ場試験における被覆内透過光の分光スペクトル 測定日時：2012年 6 月 29 日13時
処理後の新芽葉厚を図 8 に示した。葉厚に は紫外線除去による有意な減少が認められ, 紫外域光が除去されたUVカット区で薄く, 紫外域光が含まれた塩ビ区で厚かった。次に 新芽中の遊離アミノ酸とMMSC, カテキン 類, カフェインの含有量を表 6 に示した。ア スパラギン酸とグルタミン酸，セリン，テア ニンの含有量はUVカット区が有意に高く, アスパラギンとグルタミン，アルギニンの 含有量には有意な増減は認められなかった。 MMSC及びカフェインの含有量はUVカット 区が有意に高かった。カテキン類の含有量は, 個別值, 合計值とも紫外線の除去による有意 な増減は認められなかった。

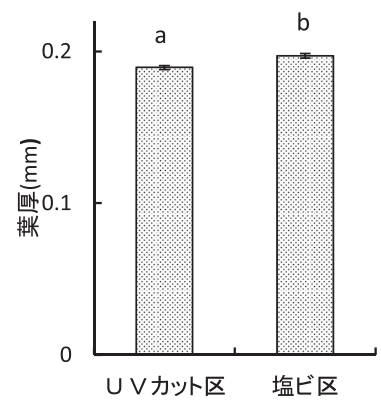

图 8 紫外線除去が被覆茶の新芽葉厚に及ぼす影響 ‘さみどり”8年生茶園を供陚した。 エラーバーは標準誤差を示す。

図中の異なる英小文字間には，5\%水準の有意差あり（検定， $\mathrm{n}=80$ )。

表 6 紫外線除去が被覆茶新芽中の遊離アミノ酸, MMSC, カテキン類, カフェイン含有量に及ぼす影響

\begin{tabular}{|c|c|c|c|c|c|c|c|c|c|}
\hline \multirow[b]{2}{*}{ 試験区 } & \multicolumn{8}{|c|}{ 遊離アミノ酸 $\quad\left(\mathrm{mg} \cdot \mathrm{g}^{-1} \mathrm{DW}\right)$} & \multirow{2}{*}{$\begin{array}{c}\text { MMSC } \\
\left(\mu \mathrm{g} \cdot \mathrm{g}^{-1} \mathrm{DW}\right)\end{array}$} \\
\hline & $\begin{array}{l}\text { アスパラ } \\
\text { ギン酸 }\end{array}$ & $\begin{array}{l}\text { グルタ } \\
\text { ミン酸 }\end{array}$ & $\begin{array}{l}\text { アスパ } \\
\text { ラギン }\end{array}$ & セリン & グルタミン ア & アルギニン & テアニン & 計 & \\
\hline UVカット区 & $1.8 \mathrm{a}$ & $3.0 \mathrm{a}$ & 0.4 & $0.3 \mathrm{a}$ & 0.4 & 1.0 & $8.8 \mathrm{a}$ & $15.7 \mathrm{a}$ & $16.6 \mathrm{a}$ \\
\hline 塩ビ区 & $1.1 \mathrm{~b}$ & $1.7 \mathrm{~b}$ & 0.2 & $0.2 \mathrm{~b}$ & 0.3 & 0.3 & $4.6 \mathrm{~b}$ & $8.4 \mathrm{~b}$ & $10.8 \mathrm{~b}$ \\
\hline \multicolumn{10}{|c|}{$\left(\mathrm{mg} \cdot \mathrm{g}^{-1} \mathrm{DW}\right)$} \\
\hline 試験区 & $\begin{array}{l}\text { エピガロ } \\
\text { カテキン }\end{array}$ & \multicolumn{2}{|c|}{ エピカテキン } & $\begin{array}{l}\text { エピガロカテ } \\
\text { キンガレート }\end{array}$ & $\begin{array}{l}\text { エピカテキ } \\
\text { ンガレート }\end{array}$ & \multicolumn{2}{|c|}{$\begin{array}{l}\text { カテキン類 } \\
\text { 計 }\end{array}$} & カフェイン & \\
\hline UVカット区 & 27.1 & \multicolumn{2}{|c|}{9.9} & 54.5 & 15.4 & \multicolumn{2}{|c|}{106.9} & $37.1 \mathrm{a}$ & \\
\hline 塩ビ区 & 26.4 & \multicolumn{2}{|c|}{11.1} & 53.2 & 16.3 & $10^{\prime}$ & 7.0 & $32.7 \mathrm{~b}$ & \\
\hline
\end{tabular}

‘さみどり’ 8 年生茶園を供試した。

異なる英小文字間には，それぞれの試験内で5\%水準の有意差あり（t検定， $\mathrm{n}=4$ ) 


\section{4 考察}

本報では分光放射計を用いて被覆内の実 際の光環境を測定し, 本ず被覆内では黒色 化繊被覆内に比べて短波長側の光が少なく, $680 \mathrm{~nm}$ 以上の長波長域光が多く含まれること を明らかにした。また本ず区には紫外域光が ほとんど透過しておらず, 一番茶後期被覆期 間中の本ず区の紫外線強度を黒色化繊区に対 する比率で示すと，4月25日から 5 月18日ま での平均值が $17 \%, 5$ 月 18 日以降の平均值が $44 \%$, 期間を通じた平均值では $29 \%$ 小さか った（図 3 )。 5 月18日以降の紫外線強度が 大きいのは, 雨や風等によりわらの位置がず れ, 遮光率が低下したためと考えられた。図 2 に示した分光透過率の比較から黒色化繊区 の光透過性が非選択的であるのに対して, 本 ず区の光透過性は選択的であるといえたが, この結果は神田ら ${ }^{2)}$ が示した各資材の分光 透過率とほほ一致した。従って, 本ず被覆内 の光環境は遮光資材の持つ光質選択性を反映 したものと考えられた。また, 本ず被覆は黒 色化繊被覆より680nm以上の長波長域光をよ り多く透過することから, 被覆内の温度が高 くなることも考えられるが, 両者の被覆内温 度にはほとんど違いがないことを確認してい る ${ }^{\dagger 3)}$ 。

一般に被覆茶の生葉の葉厚は, 玉露はもと より特にてん茶において, 荒茶の品質に大き な影響を及ぼす重要な特性であり, 葉厚の薄 い原料葉ほど色沢に讶えがあり, 外観, から 色ともに優れた製品が得られる ${ }^{15)}+4$ 。著者 らも本ず被覆で栽培された原料葉の方が黒色 化繊被覆で栽培されたものより手触りが柔ら かいことを経験的に認識していたが，本試験 から紫外線を除去することにより葉厚が薄く なることが明らかとなり, 紫外線が除去され ることが本ず被覆茶の品質が優れる一因と考
察され, 経験的な知見を裏付ける結果が得ら れた。葉厚はUV-B (280-320nm) 照射によ り厚くなることがいくつかの作物で報告され ており,この現象は植物の防衛機構のひとつ と考えられている ${ }^{16)}$ 。本試験で確認したチャ の葉厚変化も紫外線適応反応によるものと考 えられ, 苗試験の紫外線照射区で葉が厚くな ったのも300-320nmの紫外線が含まれていた ためであり，ほ場試験のUVカット区で葉が 薄かったのもUV-Bが除去されたためと考え られた。苗試験の紫外線除去区では新芽の葉 の縁が写真 2 のように波打ち, 一方紫外線を 長く照射した区では葉の縁が波打つことはな く形態が異なった。実際の栽培条件下におい ても, 本ず被覆の新芽は葉縁が波打ち, 黒色 化繊被覆のものとに形態的な違いが観察され る。こうした形態変化も紫外線の多寡に起因 する現象と推察された。

1 年生扦し木苗を用いて, 紫外線の照射や 除去が新芽の品質関連成分の含有量に及ぼす 影響を調査したところ，紫外線を除去するこ とで遊離アミノ酸含有量が増加することが 明らかとなった (表 4$)$ 。この結果は, 遮光 下で新芽の遊離アミノ酸が増加するとした 従来の知見 ${ }^{17)}$ と一致し本試験でのPPFDは,

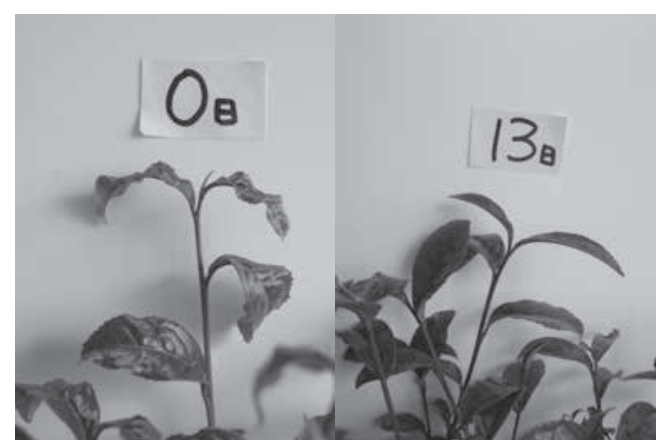

写真 2 紫外線照射による新芽形態の変化 左図：紫外線照射 0 日区, 右図 : 紫外線照射13日区 撮影日：2012年10月 4 日，品種：‘さみどり”

†4 京都府立茶業研究所：昭和53年度試験成績書（栽培)，1-39（1978） 
+ UV処理が $10.5 \mu \mathrm{mol} \cdot \mathrm{m}^{-2} \cdot \mathrm{s}^{-1}, \quad-\mathrm{UV}$ 処理が $10.8 \mu \mathrm{mol} \cdot \mathrm{m}^{-2} \cdot \mathrm{s}^{-1}$ とほぼ同等であり, 紫外線 強度のみが異なっていることから, 光の強さ だけでなく紫外線強度も遊離アミノ酸の含有 量に影響を及ぼしたと考えられた。また，ほ 場試験においてもUVカット区の遊離アミノ 酸含有量が有意に高くなった(表 6 )。しかし, 有意差の認められた遊離アミノ酸が, 苗試験 ではアルギニン, セリン, アスパラギン, ほ 場試験ではアスパラギン酸, グルタミン酸, セリン, テアニンであり, 苗試験とほ場試験 とで異なった点には留意が必要である。通常 の遊離アミノ酸組成は, テアニンの占める割 合が40〜 50\%程度と最も高い ${ }^{18)}$ 。ほ場試験で はほぼ通常どおりの組成であったが, 苗試験 における組成をみると, いずれの処理区も遊 離アミノ酸合計に占めるアルギニンの割合 が31〜 53\%程度と高かったのに対してテアニ ンが10 37\%と低く, 通常の茶新芽と組成が 異なっていた。苗や個葉を用いた試験では, $98 \%$ 以上強遮光下に相当する光条件下で可 溶性タンパク質が減少することが確認されて いる ${ }^{19,20)}$ 。今回の苗試験においてもPPFDが $10 \mu \mathrm{mol} \cdot \mathrm{m}^{-2} \cdot \mathrm{s}^{-1}$ 程度の光条件下であり, タン パク質の分解が促進されたものと推察された。 また,この結果はPPFDが $0 \mu \mathrm{mol} \cdot \mathrm{m}^{-2} \cdot \mathrm{s}^{-1}$ 遮 光下での小林ら ${ }^{21)}$ の試験結果とも一致する。 従って苗試験とほ場試験の結果が異なったの は, 影響の現れ方が植物体の齢により異なる ためと推察された。

MMSCは覆い香の主体である硫化メチル の前駆体である。新芽中のMMSC含有量は, 被覆に伴い増加し, 遊離アミノ酸と同様の挙 動を示す ${ }^{1)}$ 。これらの反応は強遮光によるも のと理解されるが, 本試験の結果から, 強遮 光下で紫外線を除去するとMMSC含有量が さらに高まることが確かめられ, 紫外線を除 去した光質が覆い香の向上に有効であると考 えられた。

カフェインについても強遮光下での紫外線
の除去や照射が含有量に影響し, 紫外線強度 が小さい条件下で含有量が増加した。遮光下 でカフェイン含有量が増加するのは, その 代謝分解が抑制されるためと考えられてお $り^{22)}$, 本試験の結果から, 遮光下での紫外線 強度がカフェインの代謝速度に影響すると推 察された。

苗試験では, 紫外線を除去した場合に主要 4 種のカテキン類合計量が増加し, また, カ テキン類合計量に対する遊離型カテキン（エ ピガロカテキン +エピカテキン) 及びエステ ル型カテキン（エピガロカテキンガレート+ エピカテキンガレート）の割合には紫外線照 射日数による変化がみられなかった。これら の結果は, 遮光することにより遊離型カテキ ンの含有量が露天の場合より少なくなり, カ テキン類合計量が減少するとした従来の知 見 $^{23-25)}$ とは異なった。従来の知見は，いずれ も太陽光下で遮光資材として黒色化繊を用い た試験から得られた結果である。つまり可視 光と紫外線がほぼ同じ比率で除去された条件 下で得られたものである。一方苗試験の光源 には人工光を用い, 紫外域光のみを照射また は除去したため+UV処理区では紫外域が他 の波長より突出して大きく, 処理条件の分光 スペクトルが太陽光とは大きく異なった。こ の違いがカテキン類の含有量に影響した可能 性がある。また, 苗試験では遊離アミノ酸組 成も通常とは異なっており, カテキン類につ いても影響の現れ方が植物体の齢により異な る可能性があるとも考えられた。一方，ほ場 試験ではカテキン類含有量に違いがみられな かった。ほ場試験は二番茶期に実施したため, PPFDが一番茶期の 3 倍程度と高く, 気温も 高かった。いずれもカテキン類の含有量を高 める条件である。そのためカテキン類含有量 への影響が現れにくい条件であったと考えら れる。また，本ず被覆の光質には紫外域光が ほとんど含まれていないことだけでなく，長 波長域光の透過率が高いという特徵があり 
(図 2 ), 本ず被覆栽培茶のカテキン類含有量

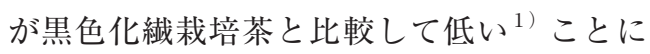
は, こうした紫外域光以外の要因が影響した 可能性も考えられる。

本報告では強遮光下における紫外域光の多 頞が, 被覆茶の品質に関わる新芽形質や品質 関連成分含有量に大きく影響することを明ら かにした。紫外線を除去した条件下で被覆茶 新芽の葉厚は薄くなり, カテキン類への影響 については検討の余地を残したものの, 茶葉 中の遊離アミノ酸とMMSC, カフェインの 含有量が増加し, 品質向上に望ましい影響を 及ぼした。本ず被覆と黒色化繊被覆では紫外 域光の透過率に大きな違いがあり，本ず被覆 内は紫外線をほとんど透過しない光環境とな る。この特性が, 新芽の葉厚を薄くし, アミ ノ酸, MMSC, カフェイン含有量を増加させ, 本ず被覆茶の品質の高さを生み出す一因であ ることが明らかになった。今後, 本ず被覆に 匹敵する高品質な茶を持続的に生産するため には，本ず被覆資材のように紫外域光透過性 が低く，かつ黒色化繊資材のように扱いが簡 便で安価な新たな資材の開発が期待される。

\section{5 摘要}

被覆内の光環境を調查したところ, 黒色化 繊被覆内の透過光は太陽光に近いスペクトル を示し，紫外域光を透過しにくいよしずやわ らで構成された本ず被覆内の透過光には紫外 域光がほとんど含まれていなかった。次に, 紫外線の照射や除去が茶新芽の葉厚と品質関 連成分に及ぼす影響を調査したところ，紫外 線を除去することにより葉が薄くなり, 遊離 アミノ酸やMMSC, カフェインの含有量が 増加することを確認した。以上の結果から, 被覆茶の品質は紫外域光の多頞に左右され, 被覆内の透過光に紫外域光をほとんど含まな いことが, 本ず被覆茶の品質の高さに寄与し ていると推察された。

\section{6 謝辞}

本研究は, (独) 科学技術振興機構平成 20 年度重点地域研究開発推進プログラム（シー ズ発掘試験 : 課題名「最高品質遮光栽培茶を 生み出す光環境の数值化」）及び農林水産省 委託プロジェクト（課題名：「生物の光応答 メカニズムの解明と高度利用技術の開発」平 成21〜25年度）によった。

\section{7 引用文 献}

1 ）木村泰子 · 原口健司 (2001)：被覆の違い による新芽の部位別の化学成分含量変 化. 京都府立茶業研究所研究報告, 23 , 57-64.

2 ) 神田真帆・藤原敏郎 (2006)：各種被覆資 材の光質選択性. 茶研報, No.102 (別), $22-23$.

3 ）中山 仰 - 土井芳憲 - 酒井慎介 (1979)： 茶樹の生育に及ぼす光質の影響に関する 研究. 茶業試験場研究報告, 15, 1-49.

4) Arakawa O.,Y.Hori and R.Ogata(1986): Characteristics of Color Development and Relationship between Anthocyanin Synthesis and Phenylalanine Ammonialyase Activity in 'Starking Delicious', 'Fuji' and 'Mutsu' Apple Fruits,J.Japan. Soc.Hori.Sci.54,424-430.

5 ) 久保田尚浩・土屋幹夫 (2001)：ブドウ果 実の着色に及ぼす成熟期の紫外光照射 の影響. 岡山大学農学部学術報告, 91 , $55-60$.

6 ) Takayanagi T.,T.Okuda,Y.Mine and K.Yokotsuka (2004): Induction of Resveratrol Biosynthesis in Skins of Three Grape Cultivars by Ultraviolet Irradiation, J.Japan.Soc.Hori.Sci, 73, 193199.

7 ) Kataoka I.,A.Sugiyama and K.Beppu (2003) : Role of Ultraviolet Radiation 
in Accumulation of Anthocyanin in Berries of 'Gros Colman' Grapes (Vitis vinifera L.), J.Japan.Soc.Hori.Sci,72,1-6.

8 ) 東尾久雄 (2007)：収穫後の野菜に対する 紫外線照射処理効果. 農業および園芸, 82, 779-783.

9 ）今泉 寛(1973)：ナスとハウス栽培にお ける光線とくに紫外線の影響について。 三重農技センター研報， 2，1-5.

10）柏木征夫 - 小林泰生・松川時晴 (1977)： プリムラ・マラコイデスの花色に及ぼす 紫外線の影響（第 1 報). 園学誌, 46 , 66-71.

11）小西茂毅・高橋英一(1969）：茶幼苗にお けるテアニンの代謝と代謝産物の再移 動. 土肥誌, 40, 479-484.

12) 後藤哲久 - 堀江秀樹 - 向井俊博 (1993)： 緑茶中の主要アミノ酸のOPAによるプ レカラム誘導体化高速液体クロマトグラ フィーによる分析. 茶研報, No.77, 2934.

13）後藤哲久 (1999)：食品の機能性評価マニ ユアル集. 農林水産省農林水産技術会議 事務局及び食品総合研究所, 5-6.

14）木村泰子 - 原口健司 - 神田真帆 (2011)： 茶葉中メチルメチオニンスルフォニウム クロライド (MMSC) の分析方法. 茶 研報, No.112 (別), 82-83.

15）辻 正樹 - 高橋成徳 - 中野隆司 - 西郷知 博 (1995)：原葉形質とてん茶品質との
関係, 茶研報, No.82 (別), 52-53.

16）野内 勇 (1997) : 紫外線（UV-B）増加 は農作物の生長・収量に影響を及ぼすか 〔2〕農業および園芸, 72，685-690.

17）阿南豊正・中川致之(1974)：茶葉の化 学成分含量に及ぼす光の影響. 茶技研, 47, 132-138.

18）後藤哲久.堀江秀樹 ·大関由紀·増田英昭· 萻科二郎 (1994）：化学成分から見た市販 緑茶の品質. 茶研報, No.80, 23-28.

19）青木 智 (1982)：被覆による茶葉光合成 機能の変化. 茶研報, No.62, 8-13.

20）青木 智 (1980)：暗黒下で誘導された茶 葉の衰退減少。茶技研, 59, 1-5.

21）小林栄人 - 中村順行 ·鈴木利和 · 大石哲 也・稲葉清文 (2011)：光強度がチャ新芽 の葉色および成分に及ぼす影響. 茶研報, No.111, 39-49.

22）鈴木建夫 (1982)：カフェイン，テオブロ ミン, テオフィリンの生合成と生分解. 化学と生物, 20, 422-424.

23）阿南豊正・中川致之(1974)：茶葉の化 学成分含量に及ぼす光の影響. 茶技研, 47, 132-138.

24）岩浅 潔(1968)：茶葉カテキン組成に及 ぼすしゃ光栽培の影響. 茶研報, No.29, 68-74.

25）西条了康・大沢キミコ(1981)：しゃ光に よるカテキン類ならびに窒素成分の生成 制御. 茶研報, No.54, 40-46. 